〔方法〕使用したMRIは旭 Mark-Jで, solid phantomとして, polyacrylamide, 多糖類の一種である curdlun，それらに $\mathrm{NiSO}_{4}$ を添加したものを用いた。

〔結果〕 polyacrylamideにより均一な $\mathrm{T}_{1}, \mathrm{~T}_{2}$ 值をも つ phantomを作成し，同程度の $\mathrm{T}_{1}$ 值を有する $\mathrm{NisO}_{4}$ solution phantom に比べて, 温度による $\mathrm{T}_{1}$ 值の変化は 軽減できた。 curdlunにより均一な $\mathrm{T}_{1}$ 值をもつ phantom を作成し得たが $T_{1}, T_{2}$ 值の温度依存性等につ いて現在検討中である.これら solid phantomの自由水 含量についても今後検討を行う予定である。

39. MRI の流速による信号強度変化（その 2 ）

東京慈恵会医科大学附属病院放射線科

○春原信雄・石田博英

平沢之規・岡本日出夫

MRI 上の画像要素として密度, $\mathrm{T}_{1}, \mathrm{~T}_{2}$, 流速がある. 今回われわれは，第42回総会（鹿児島）に引き続いて， 流速による信号強度変化をスライス厚, および $\mathrm{T}_{\mathrm{R}}, \mathrm{T}_{\mathrm{E}}$ 依存性について検討した。流速は $18 \mathrm{~cm} / \mathrm{sec} \sim 63 \mathrm{~cm} / \mathrm{sec}$ とした。スライス厚については，スライス厚が厚くなる につれて信号強度も大きくなり，また変化する周期も大 きくなった， $\mathrm{T}_{\mathrm{R}}$ 依存性については， $\mathrm{T}_{\mathrm{R}}$ を変化させると 信号強度に変化はあっても，その周期にはあまり変化は なかった、しかし， $\mathrm{T}_{\mathrm{E}}$ を変化させたときには，その周期 が変化し， $\mathrm{T}_{\mathrm{E}}$ の短い方が大きい周期となった. 流速によ る信号強度変化の周期は, スライス厚, $\mathrm{T}_{\mathrm{E}}$ に左右される ことがわかる。

\section{0. 常磁性金属イオン溶液の濃度特性と温度依存性につ} いて $\left(\mathbf{T}_{1}, \mathbf{T}_{2}\right)$

\section{東京大学医学部附属病院中央放射線部} 八木一夫・下机 茂 細野匣丈・中島準次

〔目的〕磁性体が緩和時間に影響を及ぼす因子の一つ として，常磁性金属イオンおよびそれらを含む分子の結 合状態等があげられる．常磁性金属イオンとして，Mn， $\mathrm{Cr}, \mathrm{Cu}, \mathrm{Ni}$ 等の周期律表第 3 周期化合物および $\mathrm{Gd}$ イオ ン化合物の濃度と温度依存性による緩和時間効果，さら に Gd 化合物の巨大分子による緩和時間減小効果, MRI のファントム素材適用性について研究する。

〔結果〕緩和時間の值はどの測定点においても， $T_{1}>$ $\mathrm{T}_{2}$ になり， $\mathrm{T}_{1}$ の值は両対数グラフにより濃度が薄くな るにしたがって長くなり，直線性も $\mathrm{T}_{2}$ に比べて良い。 た温度については, 測定温度が高くなると緩和時間が伸 びる傾向を示すが，逆に物質によって減小するものもあ り，物質の化学的特徵や性質をよく理解しておくことが
必要である。

\section{1.5 Tesla の超伝導 MRI における ${ }^{31} \mathrm{P}$-スペクトロ スコピーの検討}

国立循環器病センター放射線診療部

○山田幸典・片㴊哲朗・佐久間利治 坂下善治・巣組一男

${ }^{31} \mathrm{P}$-スペクトロスコピーはこれまで試料計測用 NMR では行われてきた。しかし人体用 MRIにおいては，安定 した均一高磁場の供給が困難で各メーカの研究段階にと どまって来た。今回われわれはサーフェスコイルを用い， 試料抢よび人体の筋肉よりの ${ }^{31} \mathrm{P}$-スペクトロスコピーに 成功したのでここに報告する。試料として $\mathrm{H}_{3} \mathrm{PO}_{4}, \mathrm{Na}_{3}$ $\mathrm{PO}_{4},\left(\mathrm{C}_{6} \mathrm{H}_{5} \mathrm{O}\right)_{3} \mathrm{PO}$, クレアチンリン酸, ATPを用い た。また健常者の大腿について計測を行った。後処理と して関数整形・位相変換を行いその影響を調べた，大腿 で無機りン酸，クレアチンリン酸，ATP $\alpha \cdot \beta \cdot \gamma$ ピ ークが明瞭に分離された。関数整形・位相変換は法意し て用いれば最終值へのスムージングよりはるかに有用で あった。

\section{MRI パルスパラメータにおけるエコータイムの画 像への影響}

\section{国立循環器病センター診療放射線部 \\ ○早崎正信・山田幸典・伊藤慎三 坂下善治・巣組一男}

われわれは先の第41回総会において，パルスパラメー 夕に㧍ける repetition time (TR) echo time (TE) average の信号強度および $\mathrm{T}_{1}, \mathrm{~T}_{2}$ 計算画像への影響を 検討した。しかし，その時点で TEは $35,70 \mathrm{msec}$ ので 十分な検討とは云えなかった，

今回，ソフトウェアの改良から TE 30〜 $240 \mathrm{msec}$ の任 意の選択が可能となり，また，マルチエコーイメージン グも可能となったので, TE 中心に検討する. $\mathrm{T}_{2}$ 值計算

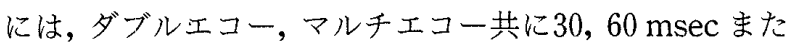
は30, $90 \mathrm{msec}$ の組合わせが広範囲に適応した。 $T_{1}$ 值計 算には，TEが短いほど忠実な值を示した。さらに，マル チエコーによる $\mathrm{T}_{2}$ 值の多点計算の可能性も示唆される.

\section{3. 同調回路の画像への影響について}

国立循環器病センター放射線診療部

○佐久間利治・山田幸典・佐野敏也

早崎正信・東儀英明・若松孝司

〔目的〕MRIの測定において, 対象試料, 患者によ り, ${ }^{1} \mathrm{H}$ のラーモア周波数に対するコイルの同調回路を， $\mathrm{S} / \mathrm{N}$ を大にするために調整している。今回われわれは， 調整時の抵抗，位相を変化させた時の画像に対する影響 